\title{
NOTE
}

\section{Light absorption by seagrass Posidonia oceanica leaves}

\author{
Susana Enríquez, Susana Agustí, Carlos M. Duarte \\ Centro de Estudios Avanzados de Blanes, Camí de Santa Bárbara s/n, E-17300 Blanes, Girona, Spain
}

\begin{abstract}
We examined the importance of pigment content and packaging within plant tissues for light absorption by Posidonia oceanica leaves from different locations along the Spanish Mediterranean coast. Pigments of $P$. oceanica leaves absorbed 70.5 to $97.1 \%$ of incident light (at $675 \mathrm{~nm}$ ): the light absorbed by pigments increased with increasing chlorophyll density. The efficiency of chlorophyll $a$ in absorbing light (i.e. the chlorophyll a-specific light absorption) also decreased significantly $(\mathrm{p}<0.001)$ with increasing pigment packaging (i.e. concentration) within the leaves, although the light absorbed per unit biomass increased with increasing pigment concentration. The positive trend between light absorption and chlorophyll density found for $P$. oceanica leaves was also found to apply to 12 other seagrass species from the Atlantic Pacific, Caribbean, South China and Mediterranean Seas The similarity between the patterns in light absorption by seagrass leaves described here and those previously described for phytoplankton suggests that these patterns reflect constraints on light absorption by phototrophic organisms which may apply to most aquatic plants.
\end{abstract}

Seagrasses are important primary producers in most tropical and subtropical areas and many temperate littoral ecosystems worldwide, where they may play a dominant role in the carbon budget. The Mediterranean seagrass Posidonia oceanica (L.) Delile is the dominant seagrass in this mostly oligotrophic sea, where its primary production can exceed that of phytoplankton. The local importance of the species is determined by the area it covers which, in turn, is closely dependent on the maximum depth it colonizes. Because the depth limit of $P$. oceanica is closely linked, like that of other seagrasses, to light penetration underwater (see review in Duarte 1991), the ability to absorb light is an important factor regulating the importance of $P$. oceanica in the carbon budget of littoral Mediterranean ecosystems.

Extensive research on light absorption by phytoplankton has provided models and empirical relation- ships demonstrating a close relationship between light absorption and the amount and extent of packaging of pigments within the cells (Morel \& Bricaud 1981, Agustí 1991a). The applicability of these relationships for marine plants other than phytoplankton, however, has only been assessed to a limited extent for some marine macroalgae (Ramus 1978). These studies have shown that the application of such theories to describing light absorption by macroalgae is confounded by complex phenomena le.g. the package effect, heterogeneous absorption, and multiple scatter), largely derived from the varied structural repertoire of the multicellular tissues of macroalgae (Ramus 1990). Yet, these theories, based on physical principles rather than properties specific to phytoplankton, may still hold for marine angiosperms, for their photosynthetic tissues (i.e. blades) are much more uniform than those of macroalgae. Here we demonstrate the importance of chlorophyll a content and its packaging within plant tissues for absorption of light by Posidonia oceanica leaves and provide evidence of the applicability of these relationships to other seagrasses.

Methods. Leaves of Mediterranean seagrasses (Posidonia oceanica, Cymodocea nodosa (Ucria.) Aschers., Ruppia maritima L. and Zostera noltii Hornemann) growing between 0.5 and $15 \mathrm{~m}$ depth were collected, between April and October 1991, from 20 locations along the Spanish Mediterranean coast. Leaves of Caribbean seagrasses (Thalassia testudinum Banks ex König, and Halodule wrightii Aschers.) were collected from different locations in the Mexican Caribbean; leaves of Atlantic seagrasses (Zostera marina L., Zostera noltii and Ruppia cirrhosa (Petagna) Grande) were collected along the South Portuguese coast; and leaves of Pacific seagrasses (Enhalus acoroides (L.) 
Royle, Thalassia hemprichii (Ehrenb.) Aschers., Halophila ovalis (R. Br.) Hook, Syringodium isoetifolium (Aschers.) Dandy, and Halodule uninervis (Forsk.) Aschers.) were collected in the South China Sea, along the Philippine coast. Light absorption was measured on fresh leaves within a few hours of collection.

Those plants collected away $(>300 \mathrm{~km})$ from our laboratory were preserved in a solution of $1.5 \%$ formaldehyde in filtered seawater, buffered to a $\mathrm{pH}$ of 7.5 with Tris, to prevent pigment degradation (Stramski 1990). We found no significant reduction in absorbance ( $t$-test, $p>0.20)$ between fresh leaves and leaves preserved for $4 \mathrm{~d}$, and no significant effect of the fixation procedure on light absorption or chlorophyll a concentration (ANOVA, $\mathrm{p}>0.20$ ), indicating that the preservation method worked efficiently. We failed, however, to obtain measurements of light absorption by the cylindrical leaves of species of the genus Syringodium sp. from the Caribbean and South China Sea, which have large air channels (den Hartog 1970). These leaves deteriorated during transportation due to failure of the preserving agent to fully penetrate inside the air-filled channels.

Light absorption was measured on intermediate leaves (i.e. leaf number $2,>50 \mathrm{~d}$ old for Posidonia aceanica), sufficiently old to have acquired the full pigmentation, but not old enough to support a significant epiphytic cover. Light absorption was measured at $675 \mathrm{~nm}$, which corresponds to a peak in absorption by chlorophyll $a$, by fitting leaf fragments mounted in microscope slides into a Shimadzu UV-2100 dualbeam scanning spectrophotometer. To avoid scattering artifacts leading to overestimation of light absorption, we placed the leaves close to the end of the photomultiplier tube and both reference and measuring beam were diffused by an opal glass unit placed in front of the photomultiplier (Shibata 1959). In addition, we corrected our measurements to exclude nonpigment absorption and residual scattering by subtracting absorbance measurements at $750 \mathrm{~nm}$ from those at $675 \mathrm{~nm}$ (Duysens 1956). The percent light absorbed by pigments was calculated from measured optical densities (O.D.) using the equation (Clayton 1973):

$$
\% \text { light absorbed }=100\left(1-10^{O \cdot D}\right)
$$

We referred the absorption measurements to the chlorophyll a density (i.e. chlorophyll a per absorption cross-section) of the leaves (Ramus 1990), which was measured spectrophotometrically on the same pieces used to measure light absorption, following pigment extraction with $80 \%$ acetone in a homogenized suspension (Dennison 1990). We calculated the thickness of the leaves examined by measuring their specific area $\left(\mathrm{mm}^{2} \mathrm{mg}^{-1}\right)$ and then assuming a density of 1.0 (confirmed in the laboratory) for the leaf material.

Results and discussion. The content of chlorophyll a in Posidonia oceanica leaves ranged widely in density ( 0.070 to $0.408 \mu \mathrm{g} \mathrm{chl} a \mathrm{~mm}^{-2}$ ) and packaging ( 0.95 to $8.91 \mu \mathrm{g} \mathrm{chl} \mathrm{a} \mathrm{mg} \mathrm{DW}^{-1}$ ). Absorption values (at $675 \mathrm{~nm}$ ) ranged between 0.53 and 1.54 O.D. ( $\log _{10}$ units), which corresponds to an absorption of 70.5 to $97.1 \%$ of the incident light (at $675 \mathrm{~nm}$ ) by chlorophyll $a$. We found the observed differences in the extent of light absorbed by pigments among leaves to be linearly related to their chlorophyll density (Fig. 1), as described by the regression equation:

$$
\begin{aligned}
& \text { Absorption }_{(675)}(\mathrm{O} . \mathrm{D} .)= \\
& 0.42+2.17 \mathrm{chl} \text { a density }\left(\mu \mathrm{g} \mathrm{chl} \mathrm{a} \mathrm{mm}^{-2}\right) \\
& \mathrm{R}^{2}=0.36 ; \mathrm{n}=80 ; \mathrm{SE}_{\text {slope }}=0.32 ; F=45.3, \mathrm{p}<0.001 .
\end{aligned}
$$

The finding that light absorption increases linearly with increasing chlorophyll density of Posidonia oceanica leaves resembles the similar linear scaling between light absorption and chlorophyll content of phytoplankton cells (Agustí 1991a). The efficiency of chlorophyll $a$ in absorbing light (i.e. the chlorophyll $a$ specific light absorption) also decreased significantly $(\mathrm{p}<0.001)$, as reported for phytoplankton (e.g. Morel \& Bricaud 1981), with increasing pigment packaging within the leaves. This relationship, albeit weak $(\mathrm{r}=-0.36)$, indicates that pigments become increasingly self-shaded as their packaging within the plant tissues increases. We found no significant relationship $(p>0.10)$ between light absorption and leaf thickness. Although the light absorbed per unit chlorophyll a produced appears to decrease as the internal chlorophyll a concentration increases, we found that, also similar to phytoplankton (Agustí 1991a, b), the light absorbed per unit leaf biomass increases linearly with increasing pigment packaging within the plant tissue (Fig. 2) as described by the regression equation:

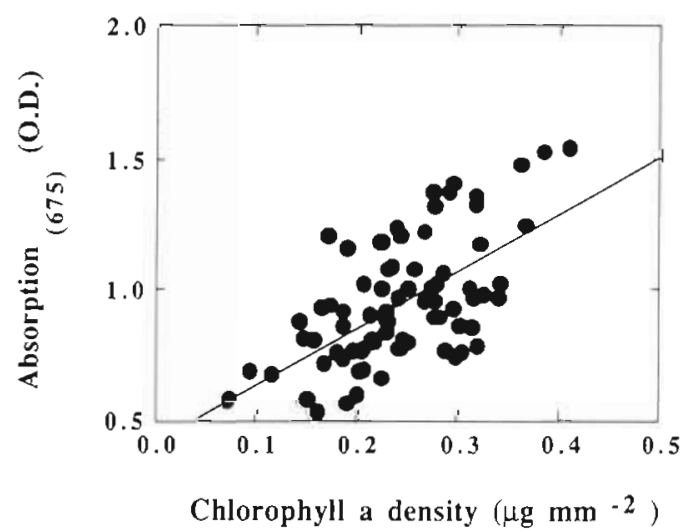

Fig. 1. Posidonia oceanica. Relationship between light absorption (at $675 \mathrm{~nm}$ ) and chlorophyll density of leaves 
Specific absorption (O.D. $\left.\mathrm{mg}^{-1} \mathrm{DW}\right)=$ $4.46+2.76 \mathrm{chl} \mathrm{a}\left(\mu \mathrm{g} \mathrm{chl} \mathrm{a} \mathrm{\textrm {mg } ^ { - 1 } \mathrm { DW } )}\right.$

$\mathrm{R}^{2}=0.49 ; \mathrm{n}=80 ; \mathrm{SE}_{\text {slope }}=0.32 ; F=75.3, \mathrm{p}<0.001$.

This equation indicates that increasing chlorophyll $a$ concentration, within the ranges measured here, results in increased light absorption per unit leaf weight. Because the quantum yield (i.e. carbon fixed per unit light absorbed) is believed to be rather constant, increasing absorption per unit weight should increase photosynthetic and growth rates of light-limited plants.

Because most seagrass species have blade-like leaves (den Hartog 1967), like those of Posidonia oceanica, the results obtained are expected to hold for most other species. This contention was supported by the observation that light absorption by leaves of other seagrass species, collected in the Atlantic, Pacific, Caribbean, and Mediterranean Sea (Table 1), followed patterns similar to those found for

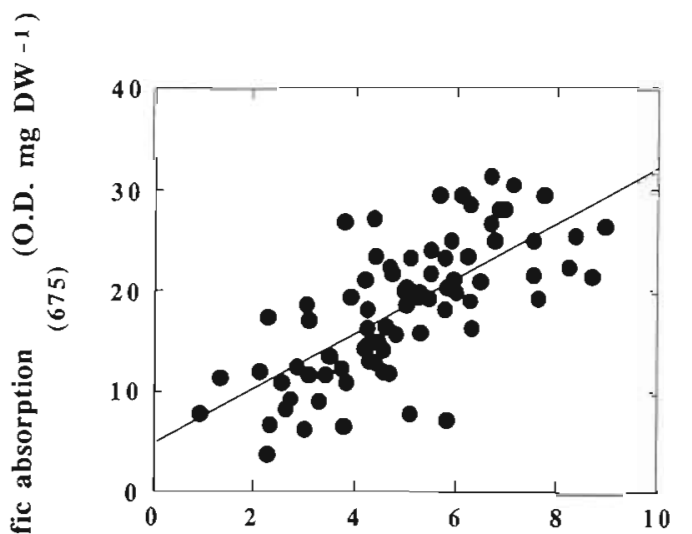

Chlorophyll a concentration $\left(\mu \mathrm{g} \mathrm{mg} \mathrm{DW}^{-1}\right)$

Fig. 2. Posidonia oceanica. Relationship between light absorption per unit weight and chlorophyll concentration of leaves

Table 1 Light absorption (as optical density and percent light absorbed by pigments), chlorophyll a density, and thickness (mean \pm SE and range) for leaves of different seagrass species

\begin{tabular}{|c|c|c|c|c|c|}
\hline Species & Origin & $\mathrm{n}$ & O.D. $(675 \mathrm{~nm})$ & $\begin{array}{c}\mathrm{Chl} \mathrm{a} \\
\left(\mu \mathrm{g} \mathrm{mm}^{-2}\right)\end{array}$ & $\begin{array}{c}\text { Thickness } \\
\text { (mm) }\end{array}$ \\
\hline Posidonia oceanica & E. Spain & 80 & $\begin{array}{c}0.94 \pm 0.026 \\
(0.53-1.54) \\
88.5 \%\end{array}$ & $\begin{array}{c}0.24 \pm 0.008 \\
(0.070-0.408)\end{array}$ & $\begin{array}{c}0.46 \pm 0.012 \\
(0.25-0.82)\end{array}$ \\
\hline Cymodocea nodosa & $\begin{array}{l}\text { E. Spain } \\
\text { S. Portugal }\end{array}$ & 40 & $\begin{array}{c}0.71 \pm 0.034 \\
(0.36-1.33) \\
80.5 \%\end{array}$ & $\begin{array}{l}0.204 \pm 0.012 \\
(0.086-0.44)\end{array}$ & $\begin{array}{r}0.50 \pm 0.026 \\
(0.22-1.00)\end{array}$ \\
\hline Enhalus acoroides & Philippines & 1 & $\begin{array}{c}0.762 \\
82.7 \%\end{array}$ & 0.0924 & 0.50 \\
\hline Halodule uninervis & Philippines & 1 & $\begin{array}{c}0.483 \\
67.11 \%\end{array}$ & 0.0863 & 0.194 \\
\hline Halodule wrightii & $\begin{array}{l}\text { Mexican } \\
\text { Caribbean }\end{array}$ & 1 & $\begin{array}{c}0.3 \\
49.8 \%\end{array}$ & 0.076 & 0.40 \\
\hline Halophila ovalis & Philippines & 1 & $\begin{array}{c}0.309 \\
50.91 \%\end{array}$ & 0.0575 & 0.091 \\
\hline Ruppia maritima & $\begin{array}{l}\text { E. Spain, } \\
\text { S. Portugal }\end{array}$ & 3 & $\begin{array}{c}0.49 \pm 0.13 \\
(0.23-0.66) \\
67.6 \%\end{array}$ & $\begin{array}{l}0.122 \pm 0.05 \\
(0.072-0.22)\end{array}$ & $\begin{array}{l}0.58 \pm 0.20 \\
(0.16-0.82)\end{array}$ \\
\hline Ruppia cirrhosa & S. Portugal & 1 & $\begin{array}{c}0.54 \\
71.1 \%\end{array}$ & 0.12 & 0.24 \\
\hline Thalassia hemprichii & Philippines & 1 & $\begin{array}{c}0.584 \\
73.94 \%\end{array}$ & 0.0838 & 0.27 \\
\hline Thalassia testudinum & $\begin{array}{l}\text { Mexican } \\
\text { Caribbean }\end{array}$ & 3 & $\begin{array}{c}0.40 \pm 0.04 \\
(0.32-0.46) \\
60.2 \%\end{array}$ & $\begin{array}{c}0.118 \pm 0.03 \\
(0.074-0.174)\end{array}$ & $\begin{array}{c}0.42 \pm 0.04 \\
(0.36-0.50)\end{array}$ \\
\hline Zostera marina & S. Portugal & 2 & $\begin{array}{c}0.74 \\
(0.69-0.80) \\
81.8 \%\end{array}$ & $\begin{array}{c}0.178 \\
(0.172-0.184)\end{array}$ & $\begin{array}{c}0.34 \\
(0.32-0.34)\end{array}$ \\
\hline Zostera noltii & $\begin{array}{l}\text { E. Spain } \\
\text { Portugal }\end{array}$ & 15 & $\begin{array}{c}0.54 \pm 0.04 \\
(0.34-0.84) \\
71.1 \%\end{array}$ & $\begin{array}{c}0.158 \pm 0.01 \\
(0.096-0.246)\end{array}$ & $\begin{array}{c}0.36 \pm 0.024 \\
(0.146-0.46)\end{array}$ \\
\hline
\end{tabular}




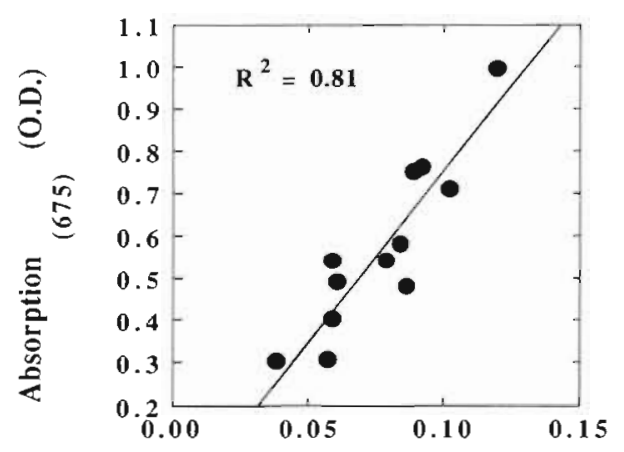

Chlorophyll a density ( $\mu \mathrm{g} \mathbf{m m}^{-2}$ )

Fig. 3. Relationship between light absorption (at $675 \mathrm{~nm}$ ) and chlorophyll density of leaves of different seagrass species. Symbols represents the mean for the leaves of each species measured (Table 1)

P. oceanica. The fraction of light absorbed by leaves of different seagrasses ranged between $50 \%$ for the small Caribbean seagrass Halodule wrightii and $90 \%$ for the large seagrass $P$. oceanica, differences in average light absorption by pigments at $675 \mathrm{~nm}$ being closely related $\left(\mathrm{R}^{2}=0.81\right)$ to the average chlorophyl density of the leaves of the 13 species examined here (Fig. 3).

The relationships described here (Figs, 1 to 3 ) indicate a close correspondence between light absorption patterns and pigment content of seagrasses and phytoplankton (cf. Morel \& Bricaud 1981, Agustí 1991a). The similarity between the light absorption patterns by seagrass leaves described here and those previously described for phytoplankton suggests that these patterns reflect physical constraints to light absorption by phototrophic organisms which should apply across all aquatic plants.

We found no effect of blade thickness on light absorption by seagrasses, contrary to the findings for phytoplankton (Morel \& Bricaud 1981, Agustí 1991a, b) and macroalgae (Ramus 1978, 1990), where light absorption is also dependent on plant thickness. The reason for this may be that seagrass leaves are relatively similar in thickness (Table 1), while phytoplankton cells and macroalgal thalli range over 100 -fold in thickness. Thus, a similarly important effect of thickness on light absorption by seagrasses would be expected if the range in leaf

This note was presented by G. W. Thayer, Beaufort, N. Carolina, USA thickness were broader, and absorption by the thick, cylindrical leaves of Syringodium sp. may deviate from the patterns described here.

Acknowledgements. This research was funded by a project funded by the Ramón Areces Foundation, funds allocated by the Spanish International Cooperation Agency, and project CI1"-CT91-0952 (HSMU) of the EC. We thank Just Cebrián and Nuria Marbá; Luis Fonseca and Esther Serrao; Margarita Gallegos and Martín Merino; and Mike Fortes and Edna Garzon for assistance while sampling in the Mediterranean, Atlantic, Caribbean, and the Philippines, respectively. This paper benefited from the comments of 2 anonymous reviewers.

\section{LITERATURE CITED}

Agustí, S. (1991a). Allometric scaling of light absorption and scattering by phytoplankton cells. Can. J. Fish. Aquat. Sci. 48: 763-767

Agustí, S. (1991b). Light environment within dense algal populations: cell size influences on self-shading. J. Plankton Res. 13: 863-871

Clayton, R. K. (1973). Light and living matter, Vol. 1, The physical part. McGraw-Hill, New York

den Hartog, C. (1967). The structural aspect in the ecology of sea-grass communities. Helgoländer wiss. Meeresunters. 15: $648-659$

Dennison, W. C. (1990). Chlorophyll content. In: Phillips, R. C., McRoy, P. (eds.) Seagrass research methods, UNESCO, Paris, p. 83-85

Duarte, C. M. (1991). Seagrass depth limits. Aquat. Bot. 40: $363-377$

Duysens, L. M. N. (1956). The flattening effect of the absorption spectra of suspensions as compared to that of solutions. Biochem. Biophys. Acta 19: 1-12

Morel, A., Bricaud, A. (1981). Theoretical results concerning light absorption in a discrete medium, and application to specific absorption of phytoplankton. Deep Sea Res. 28: $1375-1.393$

Ramus, J. (1978). Seaweed anatomy and photosynthetic performance: the ecological significance of light guides. heterogeneous absorption and multiple scatter. J. Phycol. 14: $352-362$

Ramus, J. (1990). A form-function analysis of photon capture for seaweeds. In: Lindstrom, S. C., Gabrielsen, P. W. (eds.) Thirteenth International Seaweed Symposium. Hydrobiologia 204/205: 65-71

Shibata, K. (1959). Spectrophotometry of translucence biological materials - opal glass transmission method. Meth. biochem. Analysis 7: 77-109

Stramski, D. (1990). Artifacts in measuring absorption spectra of phytoplankton collected on a filter Limnol. Oceanogr. 35: $1804-1809$

Manuscript first received: December 18, 1991

Revised version accepted: August 7, 1992 